\title{
がん難民「ゼロ」を目指す横浜市鶴見区の 緩和ケア連携と課題
}

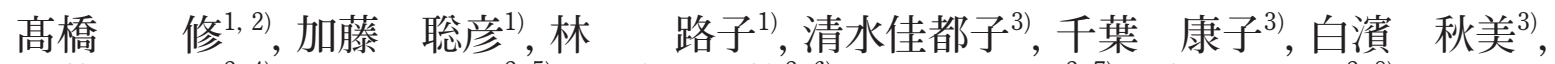 \\ 窪蔵 孝道 ${ }^{2,4)}$, 佐々木啓吾 ${ }^{2,5)}$, 長嶋敦 ${ }^{2,6)}$, 原 直 ${ }^{2,7)}$, 栗原由紀子 ${ }^{2,8)}$
}

1) 平和病院 緩和ケア科, 2)つるみ在宅ケアネットワーク, 3) 平和病院 緩和ケア病棟, 4) 汐田総合病院, 5) 佐々木病院,

6) 済生会横浜市東部病院,7) 鶴見メディカルセンター,8) 鶴見メディカル介護支援ステーション

受付日 2013 年 9 月 17 日/改訂日 2013 年 10 月 8 日/受理日 2013 年 10 月 9 日

【はじめに】がん難民「ゼロ」を目指す横浜市鶴見区の取り組みを報告する.【現状】鶴見区内には, 区外・県外でがん 治療を受ける患者も多いが, 治療終了後や状態悪化時には, 地元での療養を求められることも多い. 緩和ケア病床数は限ら れており, 緊急対応は困難である. 鶴見区では, 緩和ケアに積極的な診療所も多いが, 患者・家族の療養の場の希望は变化 し, 最後まで在宅療養が可能とは限らない. 地域連携の拠点として「つるみ在宅ケアネットワーク」が組織され, 緩和ケア の充実を目標に活動している. 当院は専門施設として積極的に関与し, 診療所に対して緩和ケア提供状況をアンケートで把 握, 在宅管理を依頼, 緊急時のバックアップを担保し, 基幹病院に対しては早期からの併診を求め, 円滑な移行を可能として いる.【課題】地域緩和ケア連携には専門施設が外来機能を強化し, 確実なバックアップを提供することが大切だが, 在宅ス タッフのスキルアップ, 緩和ケアの啓蒙, 診々連携の構築が課題である.

Palliat Care Res 2013; 8(2): 901-6

Key words: がん難民, 緩和ケア連携, 横浜市鶴見区

はじめに

がんに対する積極的な治療が終了したり, 発見時すでに治療 困難ながん患者は, 入院継続が困難となり, 在宅療養や, 緩和ケ ア提供施設への転院を求められ, 療養場所を求め, いわゆる 「がん難民」1) となる場合も多い。

緩和ケア病棟の病床数は少なく, 神奈川県全体でも 15 施設, 277 床 $^{2)}$ のみであり, 入院相談までに数力月を要する場合もあ る.さらに, 実際の入院までにも時間を要し,たどりつけない患 者も多く, 在宅療養中の患者の急激な状態悪化にも対応できな いケースがほとんどである。

良質な緩和ケアの提供のための各職種の緩和ケア連携, 教育 などの重要性が報告されている3-4). また, 各地域での緩和ケア に関する連携の取り組みが報告されているが, 連携のツール， 連携の中心となる組織などには, 各地域で特徴がみられてい $3^{5-9)}$.

区内で唯一の緩和ケア病棟を有する平和病院 (以下, 当院) を中心として, 神奈川県がん診療連携指定病院 (がん診療連携 拠点病院に準じる施設として, 県知事から指定された病院), 一 般病院, 在宅療養支援診療所, 各在宅支援施設が連携し,「がん 難民ゼロ」を目指す横浜市鶴見区の取り組みを報告する.
現 状

横浜市鶴見区は横浜北部医療圈にあり,がん診療連携指定病 院である済生会横浜市東部病院, 緩和ケア病棟を有する当院を 含む 7 カ所の一般病院がある.

\section{1 地域におけるネットワークの構築}

病々連携に関しては, 鶴見区病院診療ネットワーク委員会が 組織され,おもに地域において入院を要する患者の受け入れ, 救急対応などに関する連携について検討されている. 委員会は 3 カ月ごとに開催されており, 横浜市のモデル事業として救急 搬送困難事例を区内の各病院が輪番制で受け入れるシステム を構築し, 同様の受け入れを区内で訪問診療を受けている在宅 患者の緊急対応にまで広げる検討が行われている.

一方, 鶴見区医師会が運営する鶴見メディカルセンターで は, 2005 年から区内の診療所医師とメディカルセンターの訪 問看護師, ケアマネジャーとの情報交換会を企画し, 連携を 図ってきた. そして, 地域全体の介護事業所を含めたネット ワーク構築の必要性から, 2009 年 8 月に地域連携に関するワー キンググループを立ち上げ, 2010 年につるみ在宅ケアネット ワークが発足した. さらに, 医療側とのネットワーク強化の必 要性から区内の病院にも参加を呼びかけ,つるみ在宅ケアネッ トワーク推進検討委員会が組織された. この推進検討委員会 は, 鶴見区医師会長, 鶴見メディカルセンター長, 基幹病院の地

\footnotetext{
Corresponding author: 高橋 修|平和病院 緩和ケア科 干 230-0017 神奈川県横浜市鶴見区東寺尾中台 29-1

TEL 045-581-2211 FAX 045-581-7651 E-mail: takahashi@heiwakai.com
} 


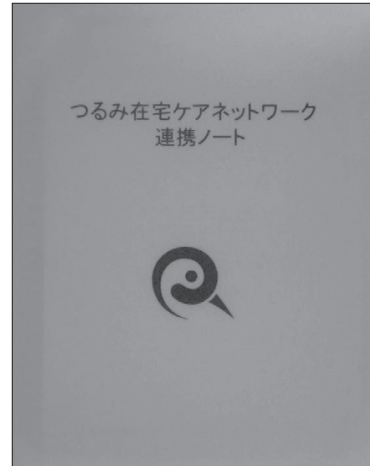

図 1

つるみ在宅ケアネットワーク連携ノート

域連携室長 (副院長), 一般病院長, 鶴見区の福祉行政担当者で 構成され, 地域における医療・介護スタッフの連携に関する勉 強会, 意見交換会, 公開勉強会などを企画運営し, 地域における 良質な緩和ケアの提供, 在宅での看取りの推進などを目標に掲 げて活動している. 合同勉強会は年 2 回, 公開勉強会は年 1 回 開催され, 合同勉強会の参加者は 2010 年の 1 回目が 75 名だっ たのに対して, 2013 年の 8 回目は 130 名の参加となり, 連携の 輪は広がりつつある。

連携のツールとしては,「つるみ在宅ケアネットワーク連携 ノート」(図 1) を作成し, 患者基本情報, 保険情報, 緊急時対応 医療機関, 居宅介護支援事業所, 訪問看護提供事業所, 検査デー 夕, 診療および看護情報提供書, 薬剂情報, 週間サービス計画表 などを挟み込み, 在宅療養患者に関わる各種スタッフの情報共 有の手段とし, 緊急入院時などには搬送先の病院医師が, 在宅 での療養状況を把握できるようになっている. 現在, 鶴見区内 の 32 施設に配布され, 632 冊が運用されている. この連携ノー トに関しての情報作成は, 現状では診療報酬上のメリットはな く, 患者の費用負担は一切発生しない.

\section{2 当院緩和ヶア科の状況}

一方, 緩和ケアの必要性のある患者に関する連携は, 緩和ケ ア病棟を有する当院が中心的な役割を果たしている.

当院の緩和ケア科が独立したのは 2008 年であり, それまで 緩和ケア科の入院はすべて一般病棟で対応していたが, 2011 年 6 月に新病院を建設, 移転の際に 16 床の緩和ケア病棟を新 設した.しかし, 緩和ケア病棟だけでの運用ではさまざまな病 状の患者の早期受け入れ, 緊急時対応には無力であるため, 一 般病棟, 医療療養病棟など, 院内のあらゆる病床を利用し, 緩和 ケア科医師 (常勤 3 名, 非常勤 1 名) が患者の受け入れを行っ ている.また, 緩和ケア科外来では, 入院相談のみでなく実際の 診療も行い, 全紹介患者の $38 \%$ が通院している.

患者の通院が困難になった場合には訪問診療も行い, 連携施 設に依頼する症例を含めた訪問診療は $12 \%$ となっているが, 連携の充実とともに当院での対応症例はむしろ減少傾向にあ る. 希望によっては在宅での看取りにも対応しているが, 全死 亡症例に対する在宅死亡率 $12 \%$ のち, 当院独自の対応は全 在宅死亡のうちの $10 \%$ である.

当院に新たに紹介受診する患者数は, 2008 年度が 54 名で あったのに対して, 2012 年度は 645 名と急増しているが, 患者 の $42 \%$ が鶴見区在住で, $30 \%$ は隣接区であり, $15 \%$ が市内・区

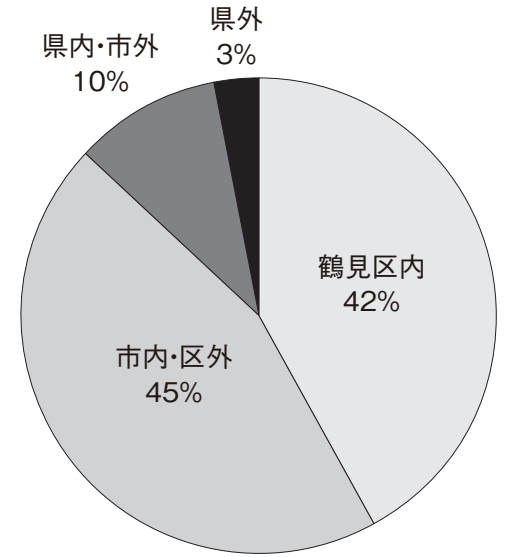

A. 患者住所

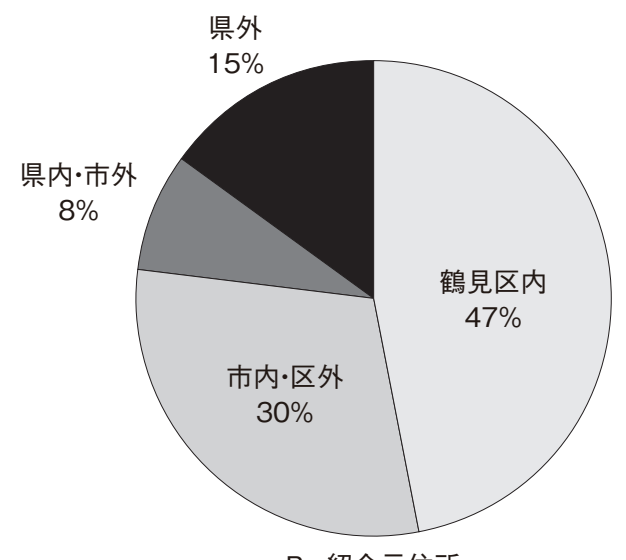

図 2 当院への紹介受診患者

外であり, 県内横浜市外 $10 \%$, 県外の患者が 3\%であった. これ に対して, 紹介元施設の所在地をみると, 区内が $47 \%$, 市内・ 区外は $30 \%$, 県内・横浜市外が $8 \%$, 県外は $15 \%$ であり, 地域 住民が, 都内などのがん治療施設で治療を受けている場合も多 いことをうかがわせた (図 2).

\section{3 当院緩和ヶア科の目標}

当院緩和ケア科の緩和ケア連携における目標は, (1) 新規紹介 患者への可及的早期対応, (2)地域における質の高い緩和ケアリ ソースの情報収集と公開, (3)患者, 家族, 医療機関, 在宅緩和ケ ア支援施設に対寸る専門施設としての各種コンサルト対応, (4) いつでも, どこでも良質な緩和ケアを受けられるための病々・ 病診・各種在宅療養支援施設との連携強化 ${ }^{9-11)}$, (5)地域全体の 緩和ケア提供スキルの向上, (6)緩和ケア専門施設完結型のケア 提供から地域・領域完結型への移行, として緩和ケア提供のモ デル地区を目指すべく活動を行っている.

\section{4 切れ目のない緩和ケアの提供}

在宅療養を継続するには, 治療早期からの緩和ケア提供の必 要性を患者, 家族, 医療者にも広く啓蒙し, 緩和ケア専門施設が 外来機能をしっかり行うことが必要と考えている. 患者, 家族 の療養の場の希望は変化する ${ }^{12}$. 外来通院が困難になった場合 にも在宅療養の継続を支える在宅療養支援診療所の関わり, 状 態の急変時や, 介護者のためのレスパイトも含め 365 日, 24 時 


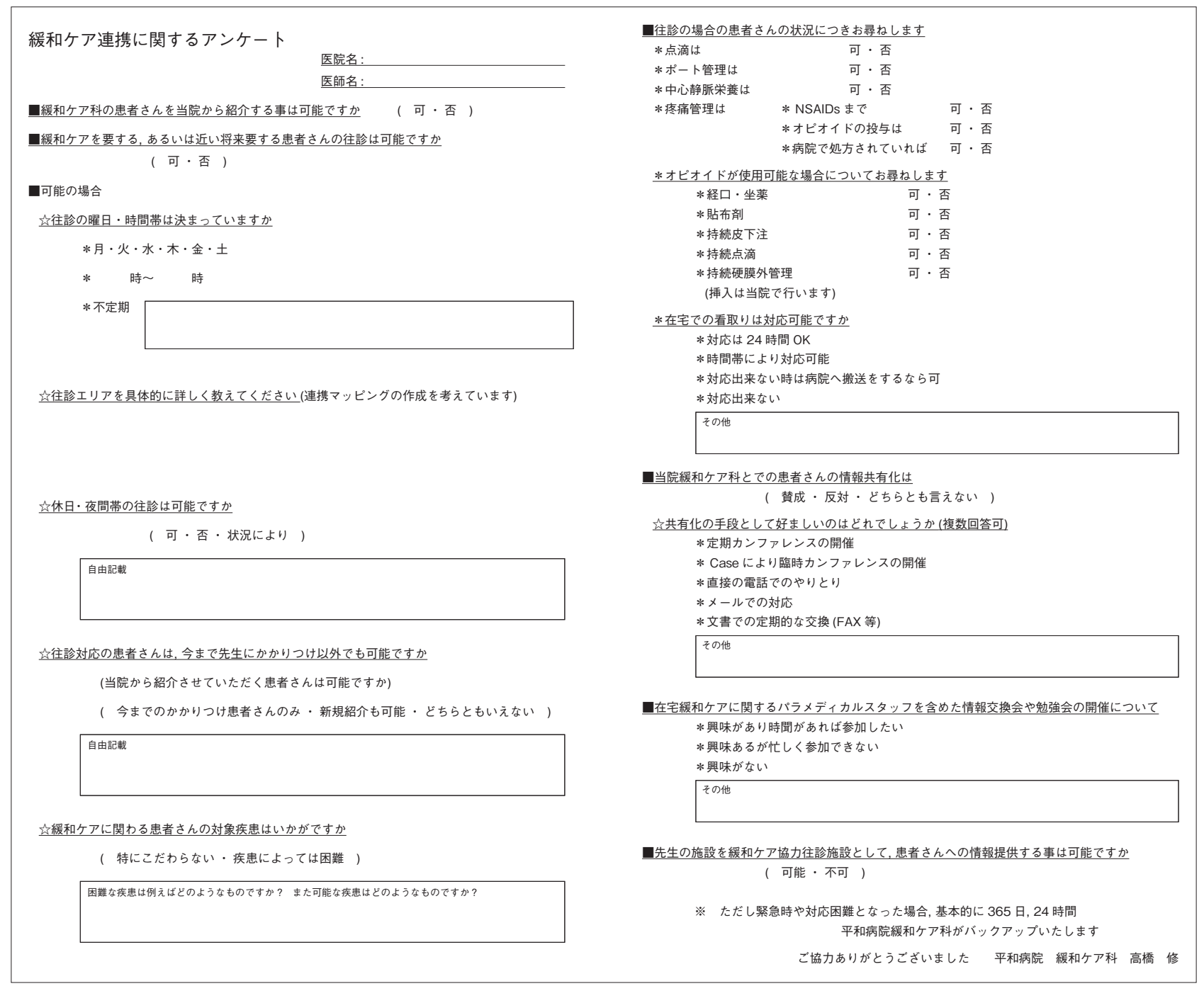

図 3 緩和ケア連携に関するアンケート

間, 確実なベッドの提供を行う体制の構築を行い, 在宅と入院 との移行を円滑に行うことが重要であると思われる.

実際, 当院緩和ケア科では, 入院患者の約 6 割が救急入院で あり, そのうちの約 4 割は再度在宅復帰が可能な状況となって いる.

\section{5 在宅療養支援診療所との連携構築}

緩和ケア提供施設が, 地域における緩和ケア継続を希望する 患者に対応可能な在宅療養支援診療所を把握, 連携することは 重要であり,つるみ在宅ケアネットワークで作成した区内の診 療所の訪問診療提供情報のうち, 緩和ケア, 在宅での看取りが 可能と回答した施設に対して, 当院は独自に作成したアンケー 卜 (図 3)を送付し, 誰が, どの地域で, どこまでの緩和ケアを提 供可能かの把握を行い, 情報公開を承諾した医療機関を当院の 「緩和ケア連携訪問診療施設」として, ホームページや院内掲 示で公開した ${ }^{11}$.

当初は区内の 9 施設であったが, 紹介患者の居住区域の広範 囲化に伴い, 対応診療所は区外, 市外を含めて 34 施設にまで増 えている (図 4). このため, 鶴見区外の患者が, 通院困難になっ た場合でも, ある程度の範囲はカバーできる体制が整いつつあ
る.

\section{6 在宅療養支援スタッフのスキルアップ}

実際に在宅療養を支えるのは医師だけではなく, 訪問看護 師, ケアマネジャー, ヘルパー, 訪問リハビリテーションスタッ フ, 訪問歯科診療医・衛生士, 地域の薬剤師などの在宅療養支 援スタッフであり ${ }^{13)}$, このスタッフの緩和ケアに対する基本的 な知識の取得は在宅での療養継続, 質の向上に大きく影響する と考えている. 当院とつるみ在宅ケアネットワークでは, 2013 年度から「在宅スタッフ向け緩和ケアスキルアップ研修」を 開催している.

この研修は, (1)緩和ケアとは, (2)緩和ケア対象者の理解, (3)緩 和ケアにおけるさまざまなインフォームド・コンセント, (4)痛 みについて, (5)(6)緩和ケアで使われる薬剤と各種症状, の 6 回 シリーズで行われ, 在宅で遭遇すると思われる, 実地に即した 内容での双方向性の研修となるような企画となっている. 参加 者は全体で 82 名 (同じ内容を 2 回, 各回 40 名程度), 内訳は訪 問看護師 30 名, 歯科医師 2 名, 理学療法士 2 名, 主任ケアマネ ジャー 8 名, ケアマネジャー 28 名, ヘルパー 6 名, 鍼尒マッ サージ師 5 名, 保健師 1 名となっている. 


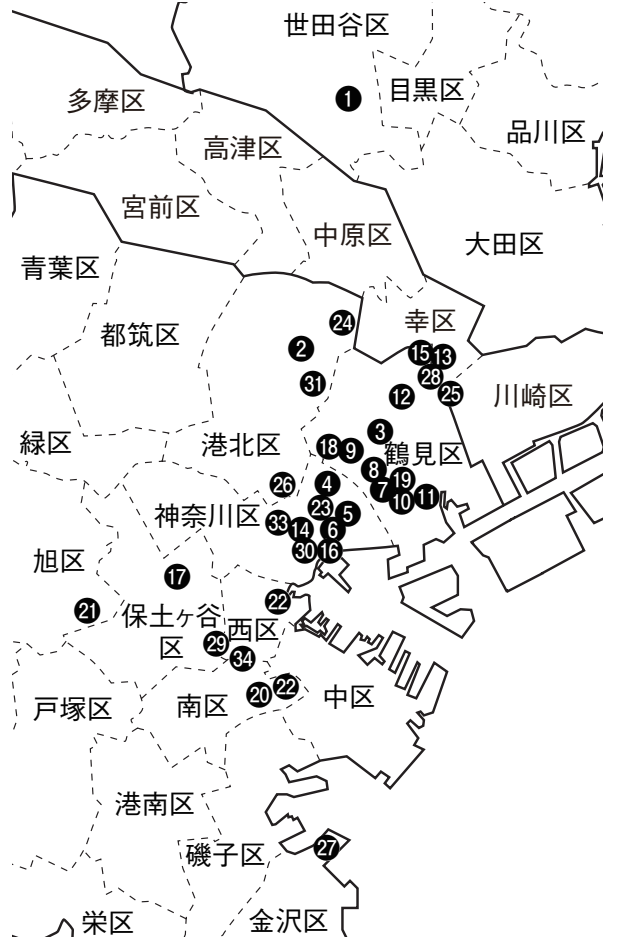

\section{図 4 緩和ケア連携訪問診療施設}

(1深沢 1 丁目クリニック, (2綱島ホームケアクリニック, 3 クリニック寺尾, (4にわメディカルクリニック, 5オルト横浜 クリニック, 6 長谷川医院, $\mathbf{7}$ 鶴見胃腸科外科医院, 8 宮下クリ ニック, $\boldsymbol{9}$ 北台診療所, (10坂本クリニック, (11渡辺医院, 12さく ら診療所, 13 三條医院, (4) 神戸医院, (15川崎幸クリニック, (16村 上医院, (17清水医院, (18古賀クリニック, (19八ートクリニック, 20睦町クリニック, (2)ゆう往診クリニック, 22 横濱高島診療所, 23さかきばらクリニック, 24日横クリニック, 25あいホームケ アクリニック, 26篠原 K クリニック, 27横浜あおぞらクリニッ ク, 28いきいきクリニック, 29保土ヶ谷在宅クリニック, 30はま かぜ診療所, 31くにもとライフサポートクリニック, 32みらい 在宅クリニック, 33 やました泌尿器科・皮フ科クリニック, 34 あいクリニックほどがや

この動きは鶴見区のみにとどまらず, 広がりをみせるように なってきており, 2013 年 10 月からは隣接の川崎市幸区, 中原 区, 川崎区の在宅スタッフ向けの同様な研修会が当院緩和ケア 科との共催で開催されるようになっている.

\section{今後の課題}

このように, 横浜市鶴見区での緩和ケア連携は目標に徐々に 近づきつつあるように感じているが，まだまだ以下のように， 改善, 発展すべき問題点も多い

\section{1 状態悪化してからの紹介}

以前に比べて, 当院緩和ケア科に紹介される患者は, 啓蒙活 動 ${ }^{14}$ 15) の効果もあり, 治療中からの併診が行われる場合も多く なった $(33 \%)$. しかし, 状態がきわめて悪化してからの紹介も まだ多く, 診療情報提供書が届いても, 状態悪化により当院初 診に至らなかった症例は 2011 年度 42 例, 2012 年度 79 例夕ら れた。

図 2 のごとく,市外・県外からの紹介患者が $23 \%$ なのに対
して, キャンセル症例の割合は $38 \%$ で,この傾向は, 特に市外・ 県外の施設で治療継続が行われている場合に多い傾向を示し ている. 診療情報提供書が届き, 初回の受診, あるいは面談前に 紹介元施設で亡くなりキャンセルとなったり, 相談にはたどり 着いても, 実際の対応前に亡くなる場合もまだまだ後を絶たな い.

当院では, 診療情報提供書が届いた段階で, 患者状況に応じ てのトリアージを行い, 初診日程の調整を行い, 初診対応時間 帯を拡大して対応している. また, 緊急を要する場合は予約外 対応を行うなじ初診対応をできるだけ早める努力をしており， 診療情報提供書が届けば, ほぼ 2 週間以内には受診可能な状態 にもかかわらず, キャンセル症例は月間で 10 名を切ることは ないのが現状である。

\section{2 介護申請の遅れ}

また, 初回受診の際, 介護保険の申請が行われていない症例 も多く, 状態の急激な悪化に在宅サービスの提供が追いつかな いケースもみられる. 初診時に介護申請を勧めることも多いた め, 新たに作成した主治医意見書は, 2011 年度が 34 例に対し て, 2012 年度は 48 例と,かなり多くなっている.

患者が亡くなった後で,「要支援」などと現実に即しない結 果が送られてくることもあり, 終末期のがん患者に対する認定 システムの見直し, 改善が望まれる.

\section{3 診々連携の構築}

地域の中で緩和ケアに精通した診療所に, 訪問診療依頼が集 中する傾向もあり, 医師の負担増につながっている. 特に, 日中 は非常勤医師が対応することが可能でも, 夜間の緊急対応や看 取りは診療所の院長が自ら行う場合がほとんどであり,この点 をお互いがカバーし合う情報共有システム, 診々連携の構築 ${ }^{16}$ が必要である。

\section{4 他地域からの患者増加}

また, 現状では鶴見区以外の地域からの患者増加により, 当 院が区外・横浜市外からの緊急対応を行う症例も増えている. 鶴見区のように, それぞれの地域で, 緩和ケア提供施設が, 外来 機能を充実させ, 患者急変時, 夜間, 休日にかかわらず確実な対 応を行うことが望まれる.

隣接区に緩和ケア病棟の開設計画が複数あるが,これらの施 設が, 緩和ケア病棟だけでなく, 当院のような外来, バックアッ プ機能をしっかりともつことが, それぞれの地域での円滑な緩 和ケア提供が可能となる必要条件であると思われる.

\section{まとめ}

横浜市鶴見区における緩和ケア連携の取り組みと, 課題につ いて報告した. なお, 本報告の要旨は第 18 回日本緩和医療学会 (2013 年 6 月,横浜) で発表した.

\section{文 献}

1) 国立がんセンターは必要か? 日経メディカル Cancer Review 2006; 2006 年冬号: 60.

2) 神奈川県ホームページ。「緩和ケア病棟のある病院一覧」 (平成 25 年 6 月 1 日現在で県が把握しているもの). 2013. 
[http://www.pref.kanagawa.jp/cnt/f417303/p443468.html]

3) Morita T, Miyashita M,Yamashita A ,et al. Effects of a programme of interventions on regional comprehensive palliative care for patients with cancer: a mixed-methods study. Lancet Oncol 2013; 14: 638-46.

4) Morita T, Kizawa Y. Palliative care in Japan: a review focusing on care delivery system. Curr Opin Support Palliat Care 2013; 7: 207-15.

5) 森嶌淳友, 来島泰秋. 在宅医療の IT 化について iPad を用い た患者情報共有における当院の試み一在宅医療ネット ワークの構築をめざして. 癌と化療２012;39(Suppl 1): 6-8.

6) 白髭豊, 野田剛稔「緩和ケア普及のための地域プロジェ クト」を中心とした長崎の取り組み. 緩和ケア 2010; 20 : 43-5.

7) 星野 彰, 関根義人, 平賀一陽.「がんになっても安心して 暮らせる町」をめざして一がん療養支援・緩和ケア部と 地域の取り組み. がん患者と対療 2012; 23: 141-4.

8) 緑川靖彦, 飯塚昌志. 在宅緩和ケアの現状. 癌と化療 2011; 38(Suppl 1): 5-7.

9) 朝比奈完. クラウド上のグループウェア・サイボウズ Live を用いた在宅医療における情報共有の試み. 癌と化療 2011; 38(Suppl 1): 17-9.

10) 新田國夫 編著. 家で死ぬための医療とケア一在宅看取り
学の実践. 医歯薬出版, 東京, 2007; 27-31.

11) 高橋 修, 加藤聡彦, 清水佳都子, 他. 終末期癌患者の在宅 医療を支援する病院と診療所の良好な連携構築一緩和ケ ア提供に関するアンケート実施による対応力把握の有用 性. 癌と化療 2012;39(Suppl 1): 21-3.

12) 日本ホスピス・緩和ケア研究振興財団. ホスピス・緩和ケ アに関する意識調查. 2012.〔http://www.hospat.org/research 1-3.html

13) 川越 厚. がん患者の在宅ホスピスケア. 医学書院, 東京, 2013; 30-40.

14) 川崎優子, 内布敦子. がん患者を含めた国民に対する緩和 ケアの普及啓発を目的としたオレンジバルーンプロジェ クトについて.緩和医療学 2009; 11: 345-50.

15) 高橋＼cjkstart修. なぜ自宅に帰れないのか一「がん緩和相談外来」 から見た終末期がん患者の在宅復帰へのバリアンス. 第 15 回 日本緩和医療学会学術大会プログラム・抄録集; 2010; 181.

16) 飯島勝矢, 吉江 悟, 木全真理, 他. 在宅医療推進における 円滑な情報共有システムを導入した新たな多職種連携の 試み一千葉県柏市における在宅医療の推進. 癌と化療 2012; 39(Supple 1): 51-4.

著者の申告すべき利益相反なし 


\title{
Clinical Practice Report
}

\section{The report of the palliative care cooperation in Tsurumi ward, Yokohama city aiming at reducing the number of "cancer refugees", who can't find the place they receive the palliative care, to "zero"}

\author{
Osamu Takahashi ${ }^{1,2)}$, Toshihiko Katou ${ }^{1)}$, Michiko Hayashi ${ }^{1)}$, Kazuko Shimizu ${ }^{3)}$ \\ Yasuko Chiba ${ }^{3)}$, Akimi Shirahama ${ }^{3)}$, Takamichi Kubokura ${ }^{2,4)}$, Keigo Sasaki ${ }^{2,5)}$, \\ Atushi Nagashima ${ }^{2,6)}$, Takashi Hara ${ }^{2,7)}$ and Yukiko Kurihara ${ }^{2,8)}$

\footnotetext{
1) Department of Palliative Care, Heiwa Hospital, 2) Tsurumi Home Care Network, 3) Palliative Care Unit, Heiwa Hospital, 4) Ushioda General Hospital, 5) Sasaki Hospital, 6) Saiseikai Yokohama East Hospital, 7) Tsurumi Medical Center,

8) Tsurumi Medical Care Management Station
}

\begin{abstract}
Introduction: We perform our trials in Tsurumi ward, Yokohama city aiming at reducing the number of "cancer refugees" to zero. State: There are many patients who receive cancer therapy outside their hometown. Once their treatment is finished due to progressive disease or deteriorating condition, they are told to leave the hospital and to get palliative care in their district. And they become so-called "cancer refugees". The beds of palliative care units are limited so the ability to accept patients in case of emergencies is poor. In Tsurumi ward, here are a lot of home care clinics providing palliative care but the place patients want to be or receive palliative care when their condition deteriorates isn't fixed. We organized the "Tsurumi Homecare Network" as the core of medical cooperation, and have worked on improving palliative care and increasing patients who die at home. Specifically, our hospital has played a central role as a special place for palliative care, we send out our original questionnaire to home care clinics to find out how they perform palliative care and introduce patients to the appropriate clinic. Patients who are in need of hospitalization are assured acceptance. On the other hand, we propose the cancer treatment hospitals to follow their patients together with us from their early stage of cancer treatment. Problem: To maintain a good relationship for regional palliative care, improving the management for outpatients, strict and timely backup system, advanced quality of homecare-supporting staff for palliative care and cooperation between home care clinic doctors are necessary. Palliat Care Res 2013; 8(2): 901-6
\end{abstract}

Key words: cancer refugees, palliative care cooperation, Tsurumi ward Yokohama city 